\title{
Social development mechanism of an agricultural enterprise formation
}

\author{
Aigul Klychova ${ }^{1, *}$, Guzaliya Klychova ${ }^{1}$, Alsou Zakirova $^{1}$, Rashida Sungatullina ${ }^{2}$, Kamil \\ Mukhamedzyanov ${ }^{3}$ and Ekaterina Philippova ${ }^{l}$ \\ ${ }^{1}$ Kazan State Agrarian University, Department of Accounting and Audit, 420015 Kazan, Russia \\ ${ }^{2}$ Vyatka State Agricultural Academy, Department of Accounting and Finance, 610018, Kirov, Russia \\ ${ }^{3}$ University of Management "TISBI", Department of Accounting and Taxation, 420012 Kazan, Russia
}

\begin{abstract}
The object of the research is to determine the major lines in forming the social process mechanism and elaborate the recommendations on improving the social policy of agricultural farming community. The article examines the social factors, indicates the trends of making management decisions on the social process of agricultural enterprise, reviews the theoretical aspects and outlines the basic arrangements of forming the social process mechanism, proposes the milestones of forming and implementing the social policy system, as well as defines the method of analyzing social process. The elaborated recommendations on improving the social policy of agricultural farming community, which consist in selecting effective forms and methods of satisfying the demands of different social groups and their sources of financing, are of practical importance.
\end{abstract}

\section{Introduction}

A socially oriented economy can be defined in modern conditions as a special business pattern. Its goal is achieved on the basis of the balance of interests of all participants in the production process and with due regard of the specific requirements to an enterprise development strategy. The strategy of socio-economic development is a key constructive element in terms of a strategic planning for a modern agricultural enterprise activity, designed to provide a comprehensive solution to long-term social, economic, scientific and technical problems. At present, the administration of the majority of agricultural enterprises is not fully aware of the need for the priority solution of social goals and objectives, considering the solution of a social issue as an exceptional prerogative of state bodies. At the same time, a significant role in the process of implementing the mechanism of social support is played by the social activity of business, which is carried out within the scope of the company activities of organizations.

In this respect, further study of theoretical aspects and elaboration of practical recommendations appears necessary for improving the mechanism of social development, creating a favorable image as an employer, etc.

\footnotetext{
${ }^{*}$ Corresponding author : skusha@bk.ru
} 
Social activities involve specific activity of the organization aimed at improving social status of a category of people or a community group. The process of implementing social activities entails the creation of legal, technical, economic, and organizational conditions for the realization of a set goal. Execution of social events results in the improvement of form and system of salary payment, its size increase; establishment of employee benefits, additional payments for work in difficult and harmful conditions; provision of job placement; social and cultural services; social benefits to the families with children and to pensioners; medical care as well as training and retraining of personnel, etc.

The economic literature operates various definitions of the term "the development of an organization". The development of an organization is defined as the process of changing the internal and external environment, the interests and needs of society and a human being; wear and aging of material resources; environmental changes; technical progress; changes in the global state of the world civilization. The development shall not be construed as any changes in the structure of the object, but only the qualitative changes that are associated with transformations of the internal structure of the object, its structure, as a set of functionally interrelated elements, dependencies and relationships [1].

Individual authors characterize the term "development of an organization" as the establishment of key strategic goals and objectives, the definition of an activity direction, and allocation of resources necessary to achieve these goals [2]. Development of an organization involves its constant transformation in accordance with the changing internal and external environment [3].

Thus, after analyzing the opinions of various authors, it occurs that the development of an organization consists in a natural, expedient, and as a rule, evolutionary, controlled positive change at a predetermined time, which leads to improved solutions to various problems, qualitative changes in the internal and external environment, aimed at obtaining new results of activity.

The concept of "development" is often used in such phrases as socio-economic development, economic development, development of economy, implying, above all, any progressive changes in the economic sphere [3]. In a quantitative change, the point at issue is economic growth; a qualitative change implies a structural change, a change in the content of development, or the acquisition by the economic system of new characteristics. Social characteristics of development are often considered in addition to economic parameters, which make it possible to fully assess the degree of development of any economic subject and region [4].

Social development covers a wide range of issues related to the creation of conditions promoting cultural development, communication, recreation and full restoration of the workers capacity [5]. A company must retain and develop social infrastructure to ensure social development [6]. These factors form the social environment of the organization. Herewith, it should be noted that social factors are interrelated with technological, economic, environmental and political ones (Fig. 1). 


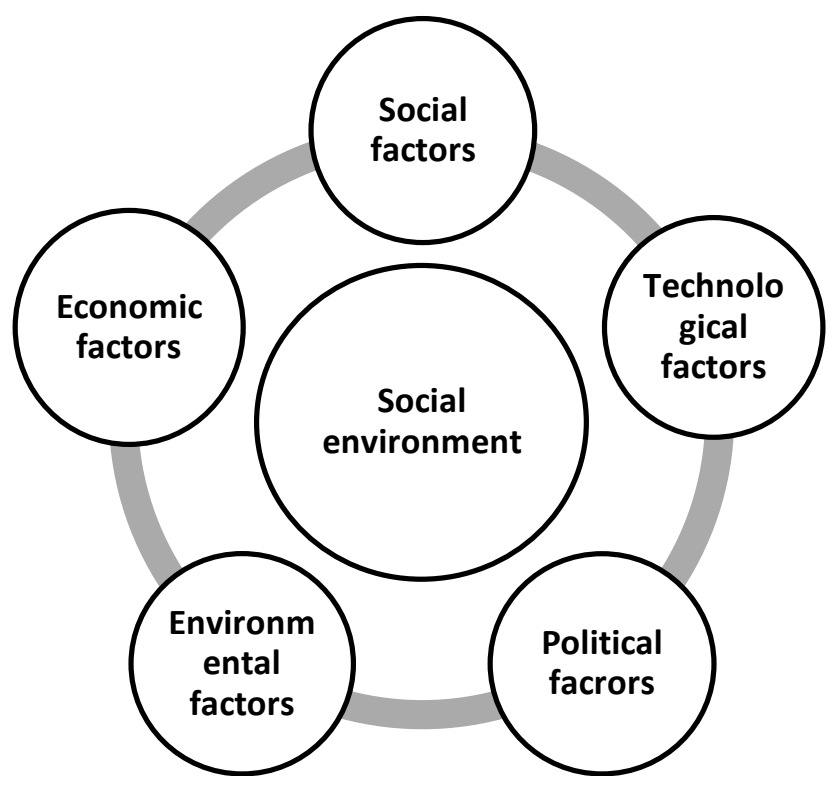

Fig. 1. Factors of social environment.

Social factors include social needs and demands, which determine the vital activity of employees in the organization, their involvement in the process of solving managerial tasks; qualitative transformation in the relationship of workers; issues related to the public life of the region of the organization location [7, 8]. Social factors include material remuneration of labor, social infrastructure, organization potential, social security, working conditions, socio-psychological climate, and leisure.

Economic factors include components which influence the process of production and distribution of material goods and serve as an indicator of the overall level of economic development and competition in the region of an agricultural organization operation. Economic factors are characterized by the growth and decline in agricultural production [9, $10,11]$, the level and rate of inflation, the credit and taxation system [12], supply and demand in the market, solvency of counterparties, the level and dynamics of prices and unemployment.

Technological factors, as a rule, depend on the innovative strategy of development chosen by the organization and are characterized by the types and structure composition of the technological processes; the quality of technological preparation of production process management, the level of automation and mechanization of technological processes, the use of energy- and resource-saving technologies [13, 14].

Environmental factors include natural resources, environmental conditions, and climatic conditions. These factors are characterized by an increase in environmental pollution and increased interference with the rational use and reproduction of natural resources, an increased control over the production of environmentally friendly products $[15,16]$.

The production and social activities of the organization are influenced by the events that occur in the political environment. The factors of the political environment include the state and political structure of society, internal and external state policy, political trends and movements $[17,18]$.

Thus, the social development of an organization is a result of the targeted influence of the considered factors in the process of people's activity and the result of the indirect impact of production on the social groups of the organization, the population of the region and consumers of the products manufactured by the enterprise. Social development is 
characterized by significant changes in organizations involved in transformation of all social processes and relationships into a qualitatively new state under the influence of external and internal factors.

\section{Materials and Methods}

Development of social environment is an indispensable object of organizational management and an integral part of personnel management.

Management of social development means rendering a premeditated, predicted, multilateral, systematic and complex impact on the social environment.

The effective management of social development requires:

- the social structure of the staff, its demographic and professional qualification structure improvement $[19,20]$;

- the number of employees regulation, and increase of their educational and culturaltechnical level [21];

- ergonomic, psycho-physiological, sanitary and hygienic, as well as other working conditions improvement, occupational safety and health of workers;

- the compliance with the workers' rights and social guarantees;

- promotion for effective work, initiative and creative attitude to the profession both through material remuneration and moral incentives;

- development and maintenance of a healthy moral and psychological atmosphere in a collective body, as well as balanced interpersonal and intergroup communications promoting well-coordinated work, disclosure of the moral and intellectual potential of each employee;

- living standard of workers and their families improvement to meet the needs for housing and home appliances, food, necessary services, non-food items [22].

Methods, techniques and procedures contributing to the settlement of social problems shall be applied in the process of the social development of an organization management. At the same time, it is necessary to apply theoretical principles and knowledge of the social processes behavior, verified social standards and accurate analytical calculations [23].

Managerial decisions on the social development of organization shall be classified along the following lines:

- an effective economy at both macro and micro levels is the basis of people's wellbeing contributing to the improvement of their living standards;

- economic success of the enterprise activity, which is influenced not only by the scale of activity and resource potential, but also by the constant demand for the products manufactured by the enterprise, and, as a result, the profit earned;

- competitiveness and effective functioning of the enterprise, which are largely ensured by the coordinated activity of its staff, united by common interests;

- high reward of joint labor, which can be achieved through an effective management of the comprehensive development at the enterprise, including permanent staff training;

- it is essential to ensure positive attitude of the workers, a benevolent moral and psychological atmosphere, confidence that he is safe from professional and social risks.

Social development of the workforce assumes significant preliminary activity, involving qualitative and quantitative changes in various spheres of life, improving social status and developing personal self-expression of its members, improving professional and social structures, shaping the system of common values. In other words, the social development of the workforce of an enterprise based on the processes of socialization of the individual employee and the workforce as a whole, allows regulating the relationship of all stakeholders [24]. 
In addition, the social development of a collective body includes a set of factors affecting social indicators of the life at an enterprise, and is realized through the implementation of mandatory and voluntary social programs developed and realized upon the initiative of the enterprise itself.

In assessing the social development of an enterprise, it is necessary to analyze in detail the costs related to the formation and development of labor potential, the use of social infrastructure, the compliance with working conditions and labor protection organization, material remuneration and social protection of personnel, formation of a sociopsychological climate in a workforce, and organization of staff recreation.

Analysis of the organization's social development costs is carried out in stages. The structure and dynamics of the total amount of social development costs are assessed at the first stage (Table 1).

Table 1. Analysis of the structure and dynamics of costs for the social development of the organization.

\begin{tabular}{|l|l|l|l|l|l|l|}
\hline \multirow{2}{*}{$\begin{array}{c}\text { Funds allocation for the } \\
\text { social development }\end{array}$} & \multicolumn{2}{|c|}{ Last year } & \multicolumn{2}{c|}{ Reporting year } & \multicolumn{2}{c|}{ Absolute deviation } \\
\cline { 2 - 7 } & $\begin{array}{c}\text { Sum, } \\
\text { thous. } \\
\text { Rub. }\end{array}$ & $\begin{array}{c}\text { Share, } \\
\%\end{array}$ & $\begin{array}{c}\text { Sum, } \\
\text { thous. } \\
\text { Rub. }\end{array}$ & $\begin{array}{c}\text { Share } \\
\%\end{array}$ & $\begin{array}{c}\text { Sum, } \\
\text { thous. } \\
\text { Rub. }\end{array}$ & $\begin{array}{c}\text { In the } \\
\text { structure, } \\
\%\end{array}$ \\
\hline $\begin{array}{l}\text { Costs of formation and } \\
\text { development of labor } \\
\text { potential at an enterprise }\end{array}$ & 350 & 5.2 & 400 & 5.5 & 50 & 0.3 \\
\hline $\begin{array}{l}\text { Costs of social infrastruc- } \\
\text { ture use at an enterprise }\end{array}$ & 300 & 4.4 & 350 & 4,8 & 50 & 0.4 \\
\hline $\begin{array}{l}\text { Costs of compliance pro- } \\
\text { vision with the labor con- } \\
\text { ditions and its protection } \\
\text { organization }\end{array}$ & 1700 & 25.2 & 1700 & 23.4 & - & -1.8 \\
\hline $\begin{array}{l}\text { Costs of remuneration and } \\
\text { benefits for the staff }\end{array}$ & 2900 & 43.0 & 3000 & 41,4 & 100 & -1.6 \\
\hline $\begin{array}{l}\text { Costs of social protection } \\
\text { of personnel }\end{array}$ & 1150 & 17.1 & 1230 & 17.0 & 80 & -0.1 \\
\hline $\begin{array}{l}\text { Costs of social and psy- } \\
\text { chological climate for- } \\
\text { mation in the workforce }\end{array}$ & 100 & 1.4 & 200 & 2.8 & 100 & 1.4 \\
\hline $\begin{array}{l}\text { Costs of the staff recrea- } \\
\text { tion organization }\end{array}$ & 250 & 3.7 & 370 & 5.1 & 120 & 1.4 \\
\hline Total costs & 6750 & 100 & 7250 & 100 & 500 & - \\
\hline
\end{tabular}

The Table 1 manifests that the largest share in the structure of expenditures for social development is occupied by the costs of material remuneration and benefits for the staff $41.4 \%$ in the reporting year. In addition, it should be noted, that in such line as the formation and development of the labor potential of the enterprise, the use of the social infrastructure of the enterprise, the formation of the socio-psychological climate in the collective body, the organization of rest of the staff, the value and the share in the cost structure has been increased.

Factor analysis of the social development costs at the enterprise is carried out at the second stage.

Distribution of funds for social development among individual employees and their categories is assessed at the third stage.

The analysis of expenses for social development in the context of personnel categories is carried out according to the form presented in Table 2.

Table 2. Analysis of the structure and dynamics of social development costs. 


\begin{tabular}{|c|c|c|c|c|c|c|}
\hline \multirow{2}{*}{$\begin{array}{l}\text { Funds allocation for the } \\
\text { social development }\end{array}$} & \multicolumn{2}{|c|}{$\begin{array}{c}\text { Management and } \\
\text { employees }\end{array}$} & \multicolumn{2}{|c|}{ Workers } & \multicolumn{2}{|c|}{ All staff categories } \\
\hline & $\begin{array}{l}\text { Sum, } \\
\text { thous. } \\
\text { Rub. }\end{array}$ & $\begin{array}{c}\text { Share, } \\
\%\end{array}$ & $\begin{array}{l}\text { Sum, } \\
\text { thous. } \\
\text { Rub. }\end{array}$ & $\begin{array}{c}\text { Share, } \\
\%\end{array}$ & $\begin{array}{l}\text { Sum, } \\
\text { thous. } \\
\text { Rub. }\end{array}$ & $\begin{array}{c}\text { Share, } \\
\%\end{array}$ \\
\hline $\begin{array}{l}\text { Costs of formation and } \\
\text { development of labor } \\
\text { potential at an enterprise }\end{array}$ & 400 & 12.4 & - & - & 400 & 5.5 \\
\hline $\begin{array}{l}\text { Costs of use of social } \\
\text { infrastructure at an en- } \\
\text { terprise }\end{array}$ & 250 & 7.7 & 100 & 2.5 & 350 & 4.8 \\
\hline $\begin{array}{l}\text { Costs of compliance } \\
\text { provision with the labor } \\
\text { conditions and its pro- } \\
\text { tection organization }\end{array}$ & 850 & 26.4 & 850 & 21.1 & 1700 & 23.4 \\
\hline $\begin{array}{l}\text { Costs of remuneration } \\
\text { and benefits for the staff }\end{array}$ & 1000 & 31.1 & 2000 & 49.6 & 3000 & 41.4 \\
\hline $\begin{array}{l}\text { Costs of social protec- } \\
\text { tion of personnel }\end{array}$ & 220 & 6.8 & 1010 & 25.1 & 1230 & 17,0 \\
\hline $\begin{array}{l}\text { Costs of social and psy- } \\
\text { chological climate for- } \\
\text { mation in the workforce }\end{array}$ & 200 & 6.2 & - & - & 200 & 2.8 \\
\hline $\begin{array}{l}\text { Costs of the staff recrea- } \\
\text { tion organization }\end{array}$ & 300 & 9.3 & 70 & 1.7 & 370 & 5.1 \\
\hline Total costs & 3220 & 100 & 4030 & 100 & 7250 & 100 \\
\hline
\end{tabular}

The Table 2 manifests, that the cost of material remuneration and staff benefits of $31.1 \%$ and $49.6 \%$ respectively comprise the largest share in the structure of expenditures for social development, both in the category "Managers and Employees" and in the category of "Workers". It should be noted that the costs of the formation and development of the labor potential of the enterprise and the formation of the socio-psychological climate in the collective body is carried out only in the category "Managers and Employees". This, no doubt, manifests a lack of social policy implementation by the management of the enterprise.

Thus, there occurs a need in development of the organizational framework for the formation of an effective social development mechanism.

\section{Results}

The methodological, legal, resource and information support form the basis of the mechanism formation of social development in the organization.

Methodological support at the state level includes laws, decrees, decrees, standards, whereas at the level of organizations, here belong collective agreements and codes.

Legal support implies the existence of a regulatory framework relating to the social policy of an enterprise, particularly corporate social responsibility.

Social resources include material and non-material means used by organizations and specialists of social services in meeting the needs of employees, groups of the population, in the provision of social services, in dealing with difficult life situations.

The sources of information support include reports, analytical calculations of special agencies, the results of marketing and sociological research, etc.

The process of formation and implementation of the organization's social policy system includes the following interrelated steps:

1. Preparatory stage: 
- research work related to social policy;

- analysis of available resources;

- explanatory work with the collective body;

- goals, methods and objectives are defined.

2. The main stage:

- implementation of a plan for the social policy formation;

- process monitoring of ongoing activities;

- adjustment of the plan for the social policy formation, if necessary;

- implementation of social policy with adjustments.

3. The final stage:

- assessment of the activities carried out;

- The results of the activities carried out are communicated to interested parties;

- social policy develops considering the changes which occur in the external and internal environment.

Both material and non-material incentives are used in the agricultural enterprises of the Republic of Tatarstan, for workers motivation within the scope of social policy implementation, which is expressed in the form of the basic salary, variable part and social benefits. In this respect, in the process of implementing social policy it is necessary to analyze the dynamics of the wages fund, the structure of employees' benefits by salary, variable part and social package, the social package budget composition for employees.

Wages are the main material type of labor motivation at agricultural enterprises. The wage fund includes permanent payments in the form of salary and variable remuneration, as well as the social compensation package. Table 3 shows the dynamics of the wages fund for 2015-2017 and its share in gross profit of one of the agricultural enterprises in the Republic of Tatarstan.

Table 3. The wages fund and financial results dynamics of the enterprise "Kolos" LLC for 20152017.

\begin{tabular}{|l|c|c|c|c|}
\hline \multicolumn{1}{|c|}{$\begin{array}{c}\text { Designation of the } \\
\text { indicators }\end{array}$} & 2015 & 2016 & 2017 & $\begin{array}{c}\text { Changes, }+/- \\
2017 \text { to } 2015\end{array}$ \\
\hline $\begin{array}{l}\text { Gross profit, thous. } \\
\text { rub. }\end{array}$ & 21010.58 & 22400.81 & 29200.2 & 8189.62 \\
\hline $\begin{array}{l}\text { Wages fund, thous. } \\
\text { rub. }\end{array}$ & 18899.02 & 19900 & 20100.57 & 1201,55 \\
\hline $\begin{array}{l}\text { Share wages fund in } \\
\text { the gross profit, \% }\end{array}$ & 89.95 & 88.83 & 68.83 & -21.12 \\
\hline
\end{tabular}

The Table 3 allows for the conclusion that the gross revenue in 2017 has increased by 8189,62 thousand rubles as compared to 2015 .

A negative fact is the downward trend in the share of the wage fund in the gross profit of the enterprise: from $89.95 \%$ in 2015 to $68.83 \%$ in 2017 . This suggests that the company focuses on the increase in wage payments. But from the position of financial management it is better to balance the payment of wages, compensation and motivational remuneration.

Undoubtedly, the social and economic development of the majority of agricultural enterprises has undergone a negative impact of financial and economic crisis. As a result, the following factors of restraining social investments in enterprises have become noticeable:

1) non-compliance with the legislatively established social and labor rights and guarantees of workers;

2) violations of labor standards on the part of the employers;

3) unjustified savings on investments in labor protection and the health of workers;

4) low wages level and payments arrears. 
Further it is necessary to systematize the data on salary payments, variable part and social package for the years 2015-2017 concerning the main categories of staff, namely managers, professionals and workers. The data is presented in Figure 2.

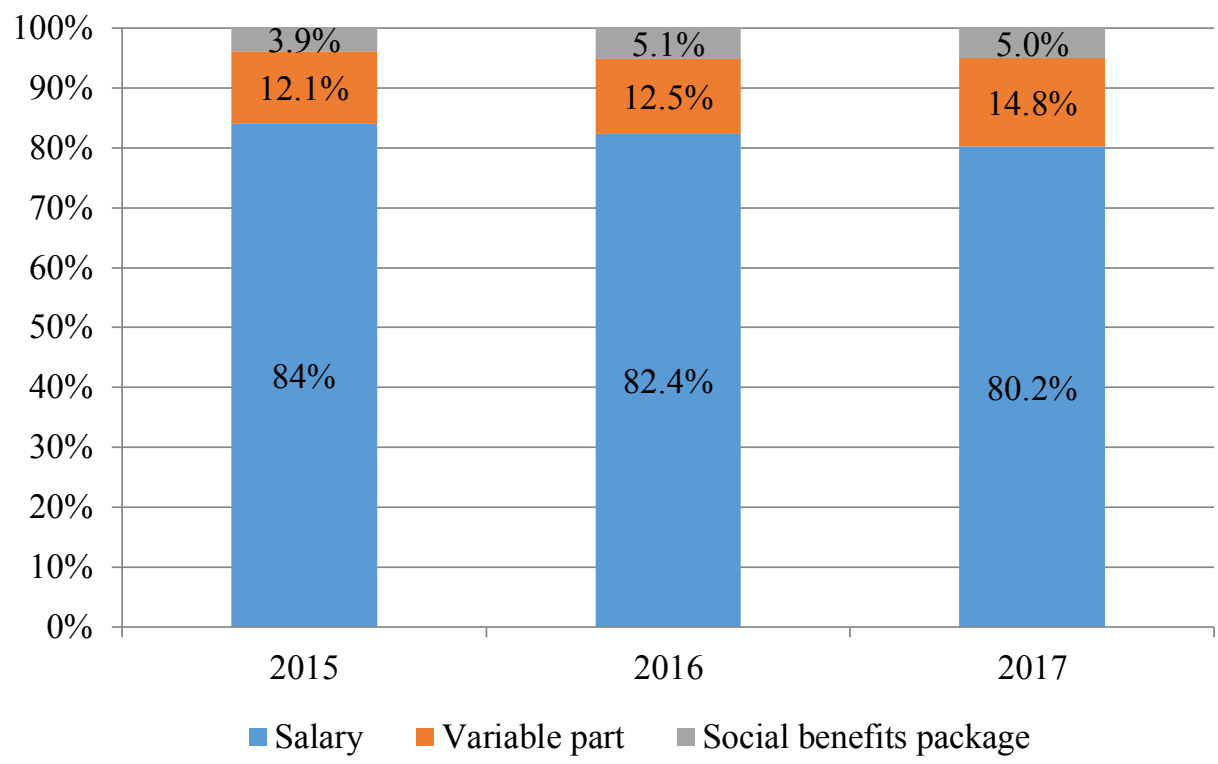

Fig. 2. Payment structure of employees' salary, variable part and social benefits package in 20152017 , in \%.

The Figure 2 manifests that the employees' salary presents the largest share of all structure in general $(84 \%, 82.40 \%$ and $80.20 \%$, respectively, for the analyzed periods), and likewise separately by personnel categories: managers, specialists and workers.

The increase in the share of the variable part and the social package payments seems positive is. But if we compare the share of payments of the variable part and the compensation package, we can conclude that the greatest emphasis is placed on incitement, rather than on the commitment formation and retention of employees, since the share of the variable part exceeds the share of the social benefits.

\section{Discussion}

Social expenditures, as a separate category, require a clear definition of the structure and classification of such expenditures, taking into account the requirements of tax, management accounting and international experience. The potential ability to meet such needs of various social groups directly depends on the volume and efficiency of the enterprise's activity and, in general, affects the total amount of taxes, contributions and other obligatory payments; current expenses of the enterprise; the amount of profit that can be directed to the realization of social and other needs.

The enterprise needs to choose an effective form and method of implementation, carry out a cost assessment of opportunities and determine the sources of funding to provide for the needs of various social groups. (Table 4).

Table 4. Means of different social groups needs realization and their financing sources.

\begin{tabular}{|l|l|c|}
\hline $\begin{array}{l}\text { Social } \\
\text { groups }\end{array}$ & Means of needs realization & Needs financing sources \\
\hline
\end{tabular}




\begin{tabular}{|l|l|l|}
\hline $\begin{array}{l}\text { Enterprise } \\
\text { owners }\end{array}$ & $\begin{array}{l}\text { Dividend payout } \\
\text { Interest by the shares accrual and payout }\end{array}$ & Profit of an enterprise \\
\hline $\begin{array}{l}\text { Enterprise } \\
\text { staff }\end{array}$ & $\begin{array}{l}\text { Labor payment } \\
\text { Provision of benefits connected with the } \\
\text { work at an enterprise } \\
\text { Labor and recreation conditions provision }\end{array}$ & $\begin{array}{l}\text { Product prime cost } \\
\text { Profit of an enterprise }\end{array}$ \\
\hline $\begin{array}{l}\text { Product } \\
\text { consumers }\end{array}$ & $\begin{array}{l}\text { Product quality increase } \\
\text { Service level increase }\end{array}$ & $\begin{array}{l}\text { Product prime cost } \\
\text { Profit of an enterprise } \\
\text { Other costs of everyday } \\
\text { activity }\end{array}$ \\
\hline
\end{tabular}

It is also necessary to improve the social policy of the enterprise by way of:

1) ensuring the obligatory conditions of social support for staff (wages, insurance, social benefits and compensations);

2) creating jobs that will be more attractive to hired staff, providing high wages, the availability of various social benefits in the form of free catering, obtaining a long-term interest-free loan opportunity at the enterprise.

In order to improve personnel service activity in respect of personnel management by in the social policy system, it is necessary to implement:

- personnel monitoring, involving permanent special monitoring of the state and dynamics of personnel, staff motivation, satisfaction with job, staff recruitment and development processes, labor discipline, work safety level, etc.;

- personnel controlling, which implies personnel information database creation; study of the existing jobs distribution impact on the results of the enterprise activity; analysis of the social and economic efficiency of personnel management methods; coordination of work with personnel planning with planning of other activity areas of the enterprise;

- personnel marketing, which involves the study of the internal and external labor market, its segmentation; analysis of employees' expectations regarding career growth; dissemination of information of the personnel needs, opportunities for vocational training or qualification changes; search and recruitment of necessary specialists;

- personnel consulting, which involves determining the need for various categories of personnel, ways to improve their skills and work efficiency; the impact of staff performance on the result of the enterprise; definition of professionally important qualities of various categories of workers; providing advice on the search, recruitment, training, use and advanced training of personnel, etc.

\section{Conclusions}

Thus, the implementation of the proposed measures will ensure the complexity of the social policy, full coverage of all spheres of working life of the employees, a dynamic response to changes and fluctuations in the external environment, effective and productive distribution of staff efforts, meeting the needs of employees, customers and the market as a whole.

The greater is the number of benefits and services provided by the enterprise and the greater is their amount established by the law, the higher will be the commitment of employees in the work at the enterprise and its successful economic activity. Herewith, this reduces the staff turnover, as an employee will hardly want to lose numerous benefits in case of a dismissal. Such a policy can ensure the availability of workers under the low wages, or it may be offered in the interests of attracting and retaining qualified labor.

Social security of workers, the development of their personality, and preservation of health is a prerequisite for the successful activity of an agricultural organization. As a motivational management resource, the socially oriented personnel policy of the enterprise and social services associated with it should encourage the employee to satisfy his needs, 
interests, and value orientations. The effectiveness of social policy consists in coordination or corresponding of the personal goals and desires of the employees with the goals of the enterprise, labor productivity and the increase in the desire of employees to work; increased social security; the encouragement of the employee's initiative in solving production problems; the improvement of moral atmosphere at an enterprise, as well as the formation of favorable socio-psychological climate, the image of the enterprise growth in the eyes of the workers and society.

\section{References}

1. J. Jiang, L. Luo, P. Xu, P. Wang, Public Health 163, 95-104 (2018) doi.org/10.1016/j.puhe.2018.06.003

2. G. Schönborn, C. Berlin, M. Pinzone, Ch. Hanisch, M. Lanz, Sustainable Production and Consumption 17, 1-10 (2019) doi.org/10.1016/j.spc.2018.08.008

3. V. Artamonov, L. Vorona-Slivinskaya, A. Medvedeva, Procedia Engineering 1651192 - 1196 ( 2016 ) doi.org/10.1016/j.proeng.2016.11.838

4. M. Hossein Zolfaghar Arani, Mediterranean Journal of Social Sciences 7(4), 139-146 (2016) doi: 10.5901/mjss.2016.v7n4S2p139

5. P. Wirutomo, Asian Social Science 10(11), 283-293 (2014) doi:10.5539/ass.v10n11p283

6. E. Ivaldi, R. Soliani, International Journal of Economics and Finance 6(5), 26-32 (2014) DOI: 10.5539 / ijef.v6n5p26

7. A.Sh. Khamzin, Y.A. Buribayev, Zh.T. Karasheva, S. Yermukhametova, A.R. Vorivodina, Mediterranean Journal of Social Sciences 6(6), 56-62 (2015) DOI: 10.5901 / mjss.2015.v6n6s7p56

8. Duong Duc Dai, Le Thi Ngan, Nguyen Thi Dien, Mediterranean Journal of Social Sciences, 4(10) 259-267 (2013) DOI: 10.5901/mjss.2013.v4n10p259

9. G. Klychova, A. Zakirova, E. Sadrieva, F. Avkhadiev, A. Klychova, E3S Web of Conferences 91, 06002 (2019) doi.org/10.1051/e3sconf/20199106002

10. Dz. Faizrakhmanov, A. Zakirova, G. Klychova, A. Yusupova, A. Klychova, E3S Web of Conferences 91, 06004 (2019) doi.org/10.1051/e3sconf/20199106004

11. G.S. Klychova, A.R. Zakirova, K.Z. Mukhamedzyanov, M.S. Faskhutdinova, Mediterranean Journal of Social Sciences 5(20), 220-224 (2014) DOI:10.5901/mjss.2014.v5n24p104

12. J. Leontieva, G. Klychova, E. Zaugarova, A. Zakirova, A. Klychova, MATEC Web of Conferences 170, 01087 (2018) DOI: 10.1051 / matecconf / 201817001087

13. A. Kola-Olusanya, Mediterranean Journal of Social Sciences 4(4), 65-71 (2013) DOI: 10.5901/mjss.2013.v4n4p65

14. G.S. Klychova, B.G. Ziganshin, A.R. Zakirova, G.R. Valieva, A.S. Klychova, Journal of Engineering and Applied Sciences 12, 4958-4965 (2017) DOI: 10,3923 / jeasci.2017.4958.4965

15. G.S. Klychova, A.R. Zakirova, K.Z. Mukhamedzyanov, E.R. Sadrieva, A.S. Klychova, Journal of Engineering and Applied Sciences 12(19), 4966-4973 (2017) DOI: 10.3923 / jeasci.2017.4966.4973

16. G.S. Klychova, A.R. Zakirova, E.R. Kamilova, International Business Management 10, 5254-5260 (2016) DOI: 10.3923 / ibm.2016.5254.5260 
17. D.G. Baluev, D.I. Kaminchenko, Asian Social Scienc 11(22), 105-109 (2015) DOI: 10.5539 / ass.v11n22p105

18. V. Kumar, M. Thakur, S. Kumar Pani, Asian Social Science 11(16), 128-136 (2015) DOI: 10.5539 / ass.v11n16p128

19. C.P. Teixeira, Mediterranean Journal of Social Sciences 4(9), 356-375 (2013) DOI: 10.5901/mjss.2013.v4n9p356

20. I.N. Valiev, Mediterranean Journal of Social Sciences 6(4), 101-107 (2015) DOI: 10.5901/ mjss.2015.v6n4s1p101

21. N. Ismajli, D. Rexha, F. Qerimi, Mediterranean Journal of Social 4(10), 548-555 (2013) DOI: $10.5901 /$ mjss.2013.v4n10p548

22. M.S. Abdullahi, Mediterranean Journal of Social. 4(8), 153-159 (2013) DOI: 10.5901 / mjss.2013.v4n8p153

23. G.R. Tsareva, V.I. Shulepov, Mediterranean Journal of Social Sciences 6(1), 554-559 (2015) DOI: $10.5901 /$ mjss.2015.v6n1s1p554

24. S. Somchan, W. Soonsornrot, The Social Sciences 11, 2230-2240 (2016) DOI: 10.3923/sscience.2016.2230.2240 